\title{
Multimedia John Paul II park - conceptual project of an educational path in the district of Czuby in Lublin
}

\section{Margot Dudkiewicz}

https://orcid.org/0000-0002-3762-6192

margotdudkiewicz@o2.pl

\section{Monika Kowalczyk}

monia_kow@op.pl

Department of Landscape Architecture, Department of Horticulture and Landscape Architecture, University of Life Sciences in Lublin

\section{Cyprian Moryc \\ kursikony@gmail.com}

The Sacred Art Workshop St. Bernardine and Bl. Nicholas at the Passion-Mary Sanctuary in Kalwaria Zebrzydowska

\begin{abstract}
Urban green areas are an important element of urban public spaces. They enable users to be in touch with nature, relax and provide a space for active recreation. Dry valleys and ravines are the place where the best design solution - in order to preserve the natural character of vegetation and terrain, and meet the recreational and leisure needs of residents - is to create a park or to introduce individual walking paths. The paper presents a conceptual design for the development of the St. John Paul II Park together with the program of educational path concerning the figure of the Polish Pope.
\end{abstract}

Keywords: ravine, educational path, St. John Paul II Park, Lublin, district of Czuby

\section{Introduction}

Lublin stands out from other Polish cities with its unique relief due to the occurrence of numerous ravines and dry valleys. These places are very often visited by city residents and tourists, serving recreational and leisure purposes. In recent years, transformation of dry valleys and ravines of Lublin is visible. Many of them are degraded by improper development and changes in the shape of the surface. Combining the green areas through ecological corridors and tracts of natural forms is a coherent structure in the urban tissue. Such systems integrate the space and positively affect the environment (Boguszewska K. and Boguszewska M. 2014).

The aim of the study is to present a new vision of development of the ravine located in the Czuby district in Lublin. The main program idea is to preserve the natural values and recreational functions of the place, as well as to introduce a new educational function, through educational path project, which aims to broaden the knowledge about the life of Saint John Paul II. This area is part of the Ecological System of Protected Areas, and is also subject to the 2002 City Council resolution concerning the local development plan for the city of Lublin, in which protection zones for areas with exceptional cultural values have been established. 


\section{Material and methods}

This work is of a review and design nature. It used both chamber studies, consisting of analyzing the content from scientific references and maps, as well as field studies. The local vision made it possible to carry out functional-spatial, compositional-observational and communication analyses. Field studies also included a general dendrological inventory and photographic documentation. Determination of tree and shrub species were made in accordance with Seneta and Dolatowski (2012).

\section{Educational paths - definition}

The first forest educational paths appeared in the 1950s in the United States. In Poland, the first such places were created in the 1970s in national parks, among others, cognitive-natural path in the Kampinoski National Park (1974). In order to develop the concept of an educational path, it is first of all necessary to set the target group of the addressees (Antczak 2007). Degree of difficulty and size of educational path depends on the natural and cultural values, but also on the location and character, and whether it is a single element in the landscape or is part of a larger educational program (Janeczko 2010). In the English-language literature, there are counterparts of the educational path, including: nature trials, education courses or trails of discovery, i.e. an exploratory path, a route connecting places related to historical, cultural and archaeological aspects of the development of society (Baud-Bovy and Lawson 2000). In Poland, educational paths are usually combined with natural environment, and less frequently - the cultural one (Bijak 2015).

\section{Ravines and dry valleys of Lublin}

There are 84 ravines and dry valleys in Lublin. Due to them, the city has a unique and priceless character. They not only contribute to the variety of landscape, but also create good conditions in terms of nature. They are a mainstay for many species of plants and animals, affect the circulation of water in the environment, cause the air movement and regulate the temperature. They play the role of the "ventilation ducts" of the city. As a result of air movements due to temperature differences, built-up urban areas are ventilated. During a day, the southern slopes heat up and the warm air rises to the top. Cool air flows down in the direction of the slope, towards the bottom of the valley. Moreover, almost all green areas have been shaped by man in cities (green squares), therefore natural places, i.e. ravines and dry valleys are particularly valuable.

Since the Middle Ages, in Lublin and the surrounding area, permanent deforestation followed, most of which was designated for agriculture. The consequence of this form of land use are erosion processes. As a result of surface erosion, the slopes were smoothed and the bottoms of dry valleys raised. However, the effect of linear erosion was the cutting up of soils. Slopes of dry valleys, due to farming and anti-erosion measures, have been slightly transformed. These areas have been preserved as green areas. Commonly, the name "ravines" is used to determine the dry valleys of Lublin. However, these are not typical ravines with steep and cliff slopes (Rodzik 2014).

In Lublin, in the 1980s, the Ecological System of Protected Areas (ESOCh) was established, the purpose of which is to connect green areas of the city of Lublin into one network. This protection covers bottoms of river valleys, dry valleys as well as green areas showing the spatial continuity (Chmielewski et al. 2013, Hryciuk et al. 2014).

\section{Teaching of Saint John Paul II in the light of nature}

In his teaching, John Paul II devoted much attention to nature. He called for actions to stop the devastation of natural environment. He argued that nature and tourism shape the spirit, perfect the personality, restore physical strength. Landscapes and other elements of the natural environment make it easier for people to concentrate, inspire and are a source of emotional experiences. He claimed that communing with nature and 
silence are conducive to contemplating God. He used every opportunity to be close to the nature; he visited beautiful corners, practiced sports, walked and swam. In the program of apostolic pilgrimage, the Pope's habitual residence in places of exceptional natural values was customarily taken into account, which also promoted them, and John Paul II gained undisputed authority in the field of respect for nature and harmonious use of its versatile values. According to the teaching of John Paul II, a modern man locked in an artificial environment full of new techniques and civilizations can experience physical, mental and spiritual fatigue. The need to be in a natural environment is almost necessary. Thanks to this, it becomes possible to experience harmony, inner peace and serenity of the spirit, due to which a man can return to everyday life and more fully develop relations with other people in a fuller way. (Pociask-Karteczka 2007).

The Holy Father appealed to stop the despotic way of nature management not only in the direct human environment, but also in the scale of the whole globe and overcome the disorderly desire to consume. Verification of the robbery and anti-ecological lifestyle was to rely on a respect for moral rights and solidary implementation of well-thought-out projects of environmental protection and peaceful coexistence with nature at the local and global level (Babiński 2012). Teaching of John Paul II is a rich source of philosophical, anthropological, moral and theological considerations on nature (Brusiło 2007). Probably for many years, papal documents with their impressive ecological message, will be a source of analysis and research (Pociask-Karteczka 2007).

During the Polish People's Republic (PRL), one of the most important moments of religious life for the inhabitants of Lublin was the visit of John Paul II during the third pilgrimage to the Homeland. On June 9, 1987, a solemn Holy Mass was celebrated in Czuby with about a million people attending. Crowds of worshipers participating in the mass also occupied the area of the ravine, where crop fields were located then (Śladkowski and Figiel 2017). The metal papal cross, which has been preserved in the place of the liturgical celebration, resembles those events. However, in the common perception of Lublin inhabitants, the entire area of the unique congregation was marked by a special emotional and sacred value, which should be protected and properly used (Pajurek 2017).

\section{Area of study}

The area under study covers about 20 ha. It is located in the district of Czuby, in the eastern part of the city. The discussed area is surrounded by the following streets: John Paul II, Roztocze and Władysław Orkan. It consists of John Paul II Park and undeveloped area of the further part of the ravine.

The developed part is a pedestrian and bicycle path, which is separates by the green belt. There are many facilities for recreation and relaxation, among others, places with benches, gazebo and amphitheater surrounded by flowerbeds and tree planting. Differently - the second part of the ravine remains undeveloped and is covered with dense vegetation. A natural terrain relief has been preserved here, which has a positive effect on the aesthetics of the place. Footpaths are designated only by well-trodden paths, which, however, makes this area difficult to access.

\section{General site inventory}

In terms of organizing the vegetation, the area can be divided into two parts. The first of them is the greenery of the John Paul II Park developed and tidy. The other is undeveloped part of the ravine with numerous self-seedlings, wild growing species and areas of high grass (Fig. 1, 2). The tree stand of the ravine consists primarily of deciduous species with predominance of Quercus robur, Betula pendula, Populus tremula, Corylus avellana, Prunus cerasifera, Robinia pseudoacacia. The shrubs are predominantly: Prunus spinosa, Crataegus laevigata, Berberis thunbergii, and Cotoneaster horizontalis. The analyzed area has a dense network of walking alleys, footsteps and bicycle routes. The most characteristic for the area of the communication node is that located in the middle of the intersection of the bicycle and walking path. This place creates a peculiar center of the present John Paul II Park. 


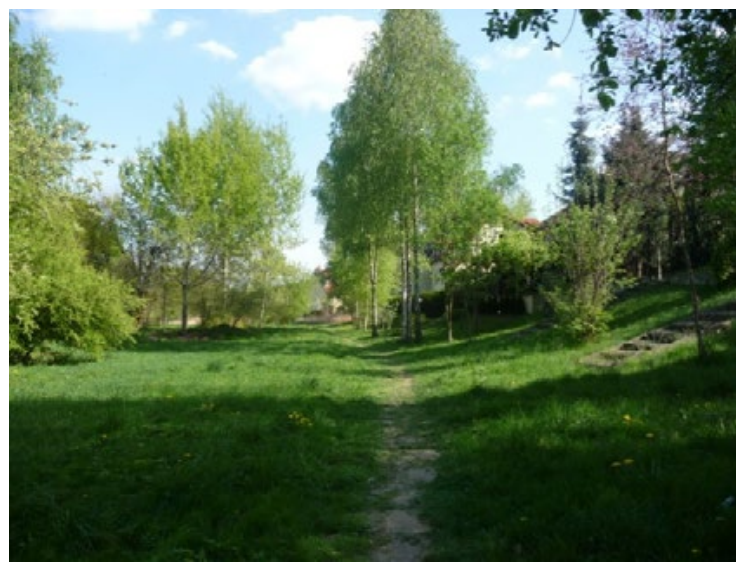

Fig. 1. Views of the undeveloped part of the ravine (photo by M. Kowalczyk)

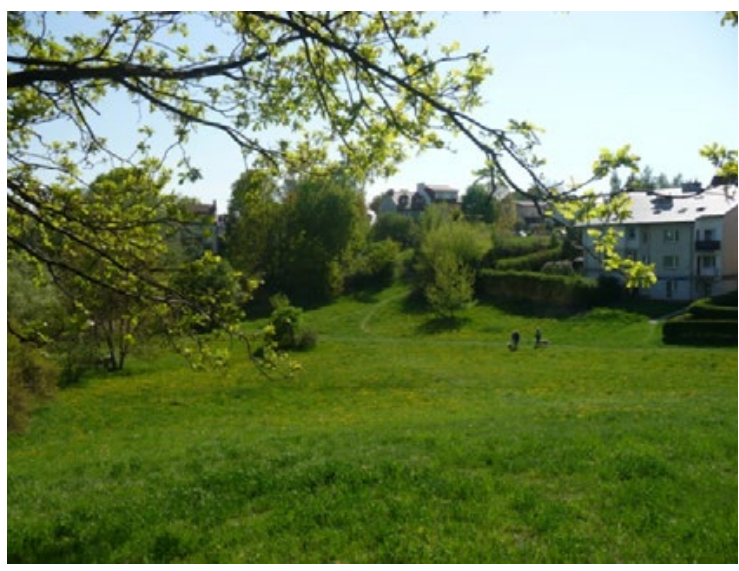

Fig. 2. Views of the undeveloped part of the ravine (photo by M. Kowalczyk)

\section{Program assumptions}

An important goal of the project is to preserve the natural green areas of the dry valley as much as possible and to minimize the interference in shaping the relief. The project aims to introduce harmony between elements of modern architecture, multimedia and sounds, and natural character of the designed place. Another goal of the project task is to create places available for people using wheelchairs. It is also important to enable the use of educational path to visually impaired people due to design of places where it is possible to listen to the statements of Saint John Paul II and comments about the nature of memories and philosophical-theological reflections connected with the message of the Polish Pope to the inhabitants of Lublin region.

The educational path is $1.4 \mathrm{~km}$ long. There are elements that testify about the character of a given place, as well as about the life of Saint John Paul II and about the idea of nature protection. The educational path offer is primarily aimed at two basic user groups. The first of them are children from primary schools, aged 9-13, who, together with the teacher, can go through this designated, marked road as part of a fieldwork by completing the work cards and completing subsequent tasks. The second group consists of young people aged 14-16. Regardless of the solutions for younger generations that are particularly preferred in the project, representatives of all age groups will be able to find something interesting on the path. The information boards will be helpful.

The project provides for numerous ways of acquiring knowledge about the Polish Pope, from reading terminals/information desks, typhlographics, performing the tasks through educational games and urban games. In addition to gaining knowledge about Saint Pope John Paul II, it was offered to place his main ideas and quotes in various parts of the proposed area. All around, the arrangement of capital letters composing the inscription: JAN PAWEt II, after the entire route that would be visible from the upper parts of the area.

The path was divided into chronological stages of the Pope's life (childhood, priesthood, pontificate, pilgrimages, illness, passing away). We tried to diversify and reflect the mood of each of the highlighted periods through color changes in the surface of the routes and the proposed vegetation.

The educational path can be traveled in two ways. The first one is a walk along the designated route, during which a visitor can read and listen to the contents of multimedia desktops, as well as perform tasks that aim, for example, to complete the statement about the facts from the life of Saint John Paul II.

As part of the second educational proposal, so-called urban game, in which several groups can compete and win points, is planned. The prepared game consists in performing tasks located throughout the Park and counting the points and time, in which the group performed all the tasks. In order to protect the instruction cards of individual tasks from destruction or loss, boxes with appropriate markings were designed for them. When passing through the Park area, the user will notice single wooden letters, arranged in the inscription "John Paul II". In each of letters, the task box was also designed. In addition, identical tasks will be found in a mobile application specially created for this purpose, and the entire field game together with the task execution points will be connected to the GPS system. 
In the designed elements of small architecture, the decorative motif will be the logo of the project (Fig. 3). It will be made from a combination of symbols associated with Saint John Paul II, among others, cross, rosary, zucchettos. The Cross is a well-known symbol of the faith of the Catholic Church. Semi-circles - symbolizing the zucchettos (headwear worn by the Pope). Circles - resembling a halo (symbol of saints), aim to draw attention to the holiness of John Paul II. Unclosed circles - symbol of the openness of Saint John Paul II to the world of nature and another man (always devoted to God and people, he was meeting others). Small circles - a symbol of the rosary beads, to practicing of which he encouraged (St. John Paul II prayed constantly to Mary himself). Number 4 - symbol of four sides of the world, recalled, because for the Polish Pope, every country in the world, as well as every human being, was extremely important as a destination and an object of concern. Described Park logo will appear on benches, educational desks and "greets" at the entrances (Fig. 4, 5).

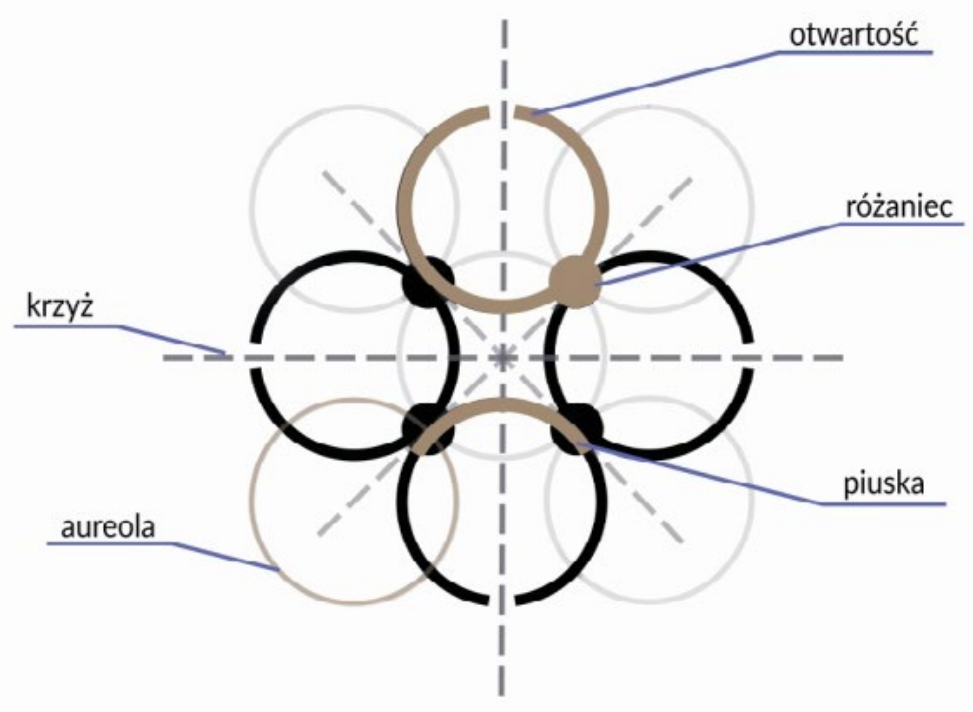

Fig. 3. Symbolism of the project logo (by M. Kowalczyk)

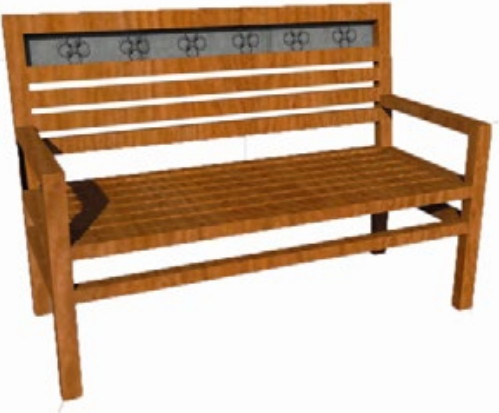

Fig. 4. Original design of the bench (by M. Kowalczyk)

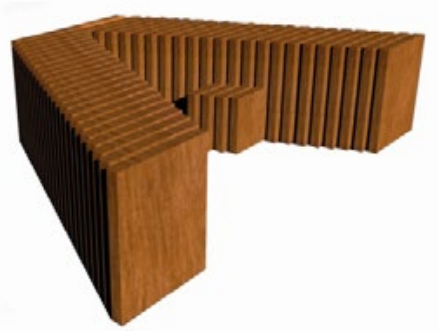

Fig. 5. Original design of the A-shaped bench (by M. Kowalczyk) 


\section{SCHEMAT FUNKCJONALNO - PRZESTRZENNY}

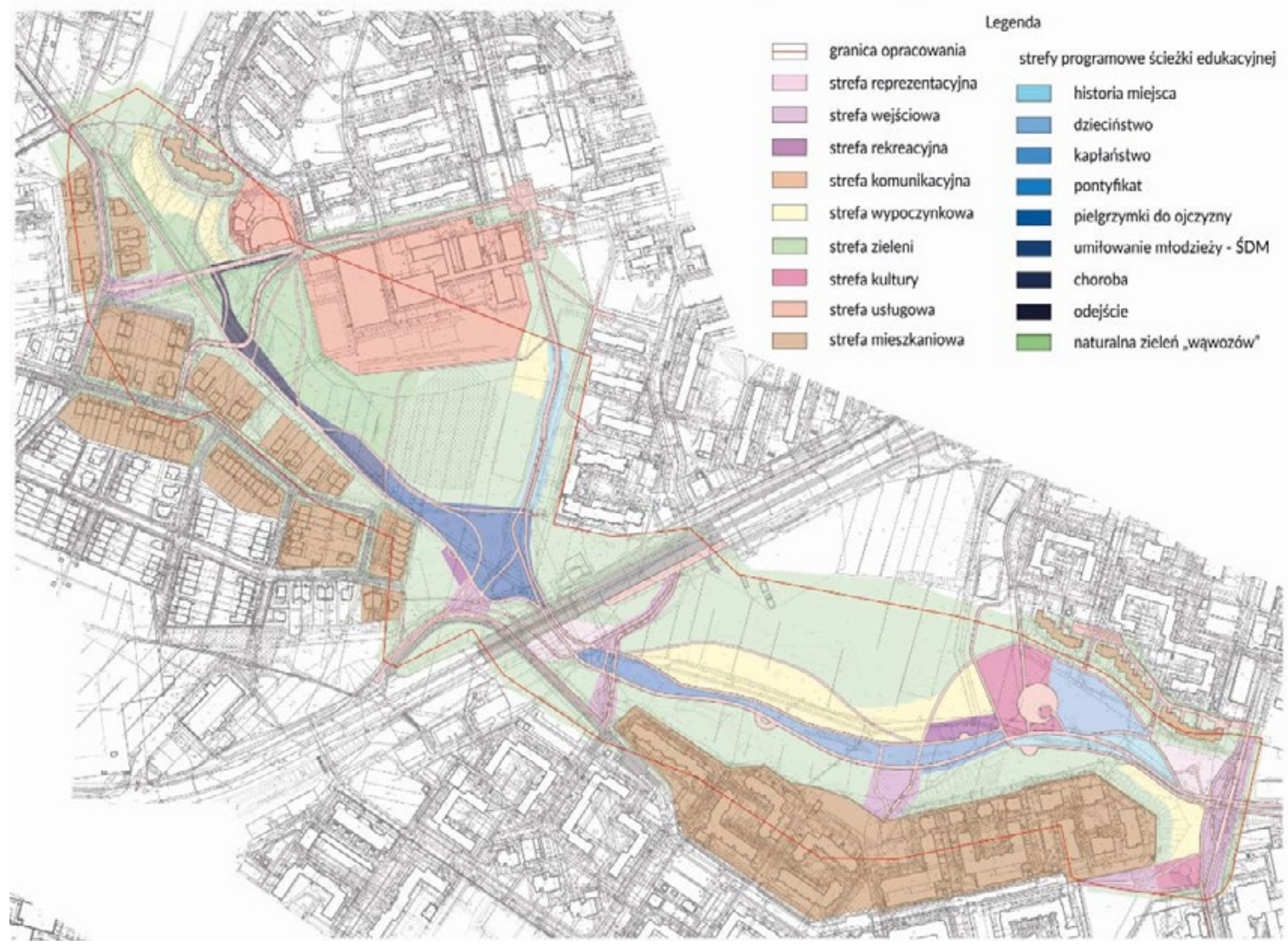

Fig. 6. Functional and spatial diagram of the Multimedia John Paul II Park in the ravine of Czuby (by M. Kowalczyk)

Due to the existence of many "wild" entrances to the ravine and footpaths, additional paths and openings to the district were designed. Due to the good condition of existing greenery and rich variety of trees and shrubs species, existing vegetation was preserved, while new routes were designed so that it would not be necessary to cut down existing trees. It has been proposed to plant the rows along pedestrian paths, as well as the flowered meadows repeated throughout the projected area (Fig. 6).

In order to increase the recreational function of the Park, it was designed to place garden chairs in sunny areas with special scenic values. Users will be able to sunbathe and relax, while admiring the views. On the same hills, in winter season, sledging will be possible.

Due to the intensity of use of the area in question, both during the day and in the evening, a larger number of lanterns was designed, as well as the introduction of new forms of lighting.

\section{Summary}

The aim of the project was to create a transparent public space, lively, with no architectural barriers, with a guiding idea based on the moral and ecological teaching of Pope John Paul II. Developed part of the ravine was extended with another, carefully composed and thought-out space, referring to already existing one, and at the same time, having an original solution in the form of an educational path. The unique qualities of the tradition and the identity of the place determined the specificity of the project and equipment of the natural space of the ravine. Presented vision is a complementary proposal that takes into account specific nature and functioning of a valuable green area in the entire city structure and a modern residential area. 


\section{Bibliography}

[1] Antczak A. 2007. Zasady tworzenia leśnej ścieżki edukacyjnej (w:) ABC edukacji leśnej, CILP, Bedoń, s. 65-80.

[2] Baud-Bovy M., Lawson F. 2000. Tourism \& recreation. Handbook of planning and design, Architectural Press, New York.

[3] Boguszewska K., Boguszewska M. 2014. Zagospodarowanie terenów zieleni miejskiej na przykładzie suchych dolin Lublina w kontekście rozwiązań projektowych z Polski i ze świata. Wąwozy i suche doliny Lublina Potencjał i zagrożenia. (red.) Ewa Trzaskowska, Lublin s. 183-194.

[4] Babiński J. 2012, „Kwestia ekologiczna” w nauczaniu Jana Pawła II, „Studia Gdańskie” T. XXX (2012), s. $249-262$.

[5] Bijak S. 2015, Nie tylko przyroda - elementy kulturowe w programie ścieżek dydaktycznych, . Studia i Materiały CEPL w Rogowie R. 17. Zeszyt 45/4/2015: 30-36.

[6] Brusiło J. 2007, Przyroda w antropologii i teologii Jana Pawła II, Przyroda, geografia, turystyka w nauczaniu Jana Pawła II ks. Maciej Ostrowski, Izabela Sołjan (red.) XV Seminarium Sacrum i przyroda, Kraków, 2007, s. 47-64.

[7] Chmielewski Sz., Łukasik A., Owczarek P. 2013. Ekologiczny System Obszarów Chronionych Miasta Lublin a miejscowe plany zagospodarowania przestrzennego. Teledetekcja środowiska 49: 7-14.

[8] Hryciuk J., Trzaskowska E., Adamiec P. 2014. Wpływ stanu zachowania i form zagospodarowania suchych dolin na walory krajobrazowe Lublina. Wąwozy i suche doliny Lublina Potencjał i zagrożenia. (red.) Ewa Trzaskowska, Lublin, s. 71-81.

[9] Janeczko E. 2010. Ścieżki edukacyjne jako element rekreacyjnego zagospodarowania lasu. Studia i Materiały CEPL w Rogowie, 1(24): 100-107.

[10] Pajurek J., 2017, 30 rocznica wizyty św. Jana Pawła II, „Ku Świętej Rodzinie”, rok III 6 (7) 2017: 2-3.

[11] Pociask-Karteczka J. 2007. Przyroda w nauczaniu Jana Pawła II. XV Seminarium Sacrum i przyroda „Przyroda, geografia, turystyka w nauczaniu Jana Pawła II". (red.) Ks. Maciej Ostrowski, Izabela Sołjan, Kraków, s. 65-86.

[12] Rodzik J. 2014. Wąwozy a suche doliny erozyjno-denudacyjne w Lublinie, Wąwozy i suche doliny Lublina Potencjał i zagrożenia Redaktor naukowy Ewa Trzaskowska, Lublin, s. 21-30.

[13] Seneta W., Dolatowski J. 2012. Dendrologia. Wydawnictwo Naukowe PWN, Warszawa.

[14] Śladkowski W., Figiel G. 2017. Lublin 700 lat dziejów miasta, Lublin. Towarzystwo Naukowe, Lublin. 